\title{
UJI BEDA PELANGGARAN TRAFFIC LIGHT BERDASARKAN LOKASI PELANGGARANNYA
}

\author{
Ridayati \\ Dosen Matematika Pada Jurusan Teknik Sipil \\ Sekolah Tinggi Teknologi Nasional \\ Jalan Babarsari No. 1, Depok-Slemanm Yogyakarta \\ ridayati@gmail.com
}

\begin{abstract}
The increasing of the vehicles flow on Yogya-Solo street causing congestion at some points in the Klaten district. The main cause of the congestion is the number of traffic violations which lead to the accidents. Bendogantungan, south Klaten, is one of the most congested point in this district. This study is aimed to determine the causes and the effects of traffic light violations and to examine the difference of traffic light violations based on the point of violations in the intersection of bendogantungan, Yogya-Solo street.

The results show that the practical mind-set of Klaten community in driving has created an instant community. Many people of that community have not realized yet on the importance of traffic regulation, this causes the number of accident. The result of analysis using SPSS 15 shows that there is a significant difference between the one way traffic violation at Empu Sedah street and eastward of Yogya-Solo street. The difference also appears between the one way traffic violations at Empu Sedah street and the westward of Yogya-Solo street. It also happens between the right turn of Ki Ageng Pandanaran street and the westward of Yogya-Solo street.
\end{abstract}

Keywords: Violation, Traffic light, One way anova

\begin{abstract}
Abstrak
Peningkatan arus kendaraan di jalan Yogya-Solo menyebabkan kemacetan lalu lintas di sejumlah titik di wilayah Kabupaten Klaten. Penyebab utama kemacetan adalah banyaknya pelanggaran lalu lintas sehingga rawan terjadi kecelakaan. Salah satu lokasi yang sering mengalami kemacetan di daerah Klaten adalah perempatan Bendogantungan, Klaten Selatan. Penelitian ini bertujuan untuk mengetahui penyebab dan dampak pelanggaran traffic Light serta menguji perbedaan pelanggaran traffic light berdasarkan lokasi pelanggarannya di simpang empat Bendogantungan jalan raya Yogya-Solo.

Hasil pengamatan menunjukkan bahwa pola pikir masyarakat Klaten yang praktis dalam berkendara di jalan raya telah melahirkan masyarakat instan baik saat berkendara maupun diluar berkendara. Masyarakat Klaten masih banyak yang belum sadar akan pentingnya peraturan lalu lintas sehingga banyak pelanggaran lalu lintas. Hasil analisis menggunakan SPSS 15 diperoleh bahwa terdapat perbedaan yang signifikan antara pelanggaran arah lurus di jalan Empu Sedah dengan pelanggaran arah lurus di jalan Yogya-Solo arah timur dan di jalan Yogya-Solo arah barat.

Perbedaan yang signifikan terjadi juga pada pelanggaran arah belok kanan di Jalan Ki Ageng Pandanaran dengan pelanggaran di jalan jogja solo arah barat.
\end{abstract}

Kata kunci: Pelanggaran, Traffic light, One way anova 


\section{Pendahuluan}

Persimpangan merupakan bagian yang tidak terpisahkan dari semua sistem jalan. Ketika berkendaran didalam kota, orang dapat melihat bahwa kebanyakan jalan didaerah perkotaan biasanya memiliki persimpangan, di mana pengemudi dapat memutuskan untuk jalan terus atau membelok dan pindah jalan. Persimpangan jalan dapat didefinisikan sebagai daerah umum di mana dua jalan atau lebih bergabung atau persimpangan termasuk jalan dan fasilitas tepi jalan untuk pergerakan lalu-lintas didalamnya (AASHTO, 2001).

Peningkatan arus kendaraan di jalan Yogya-Solo menyebabkan kemacetan lalu lintas di sejumlah titik di wilayah Kabupaten Klaten, pemasangan Lampu pengatur lalu lintas atau traffic light yang salah atau tidak tepat juga sebagai biang keladi kemacetan yang parah. Akhirnya banyak terjadi pelanggaran lalu lintas yang menjadi penyebab utama terjadinya kecelakaan. Beberapa lokasi yang sering mengalami kemacetan di antaranya perempatan Bendogantungan, Klaten Selatan, pertigaan Prambanan, pertigaan depan Rumah sakit Dokter Soeradji Tirtonegoro, perempatan Pasar Delanggu, dan perlintasan kereta api (KA) di Jalan By Pass Selatan. Selama ini jalan-jalan tersebut sudah terlalu padat arus lalu lintas karena menjadi tumpuan semua kendaraan, baik angkutan berat, mobil pribadi, sepeda motor dan truk pengangkut bahan galian golongan $\mathrm{C}$. Padahal lebar ruas jalan sudah tak sebanding dengan jumlah kendaraan yang melintas.

Berdasarkan latar belakang diatas, penulis tertarik meneliti tentang pelanggaran traffic light di simpang empat Bendogantungan jalan raya Yogya-Solo. Secara spesifik tulisan ini bertujuan untuk mengetahui faktor-faktor yang mempengaruhi pelanggaran lalu lintas dan dampak pelanggaran lalu lintas serta mengetahui beda pelanggaran lalu lintas berdasarkan lokasi pelanggarannya menggunakan uji independen t-test dan one way anova.

\section{Landasan Teori}

Dalam penelitian ini, hal penting yang menjadi dasar analisis adalah pelanggaran di simpang empat dan uji Independensi.

\subsection{Simpang Empat Jalan Raya}

Persimpangan adalah daerah di mana dua atau lebih jalan bergabung atau berpotongan/bersilangan (Hendarto, 2001). Persimpangan-persimpangan merupakan faktorfaktor yang paling penting dalam menentukan kapasitas dan waktu perjalanan pada suatu jaringan jalan, khususnya di daerah perkotaan. Jenis simpang berdasarkan cara pengaturannya dapat dikelompokkan menjadi dua yaitu simpang jalan tanpa sinyal dan simpang jalan dengan sinyal (Morlok, 1991). Pada perencanaan suatu simpang, kekurangan dan kelebihan dari simpang bersinyal dan simpang tak bersinyal harus dijadikan suatu pertimbangan. Adapun karakteristik simpang bersinyal dibandingkan simpang tak bersinyal adalah kemungkinan terjadinya kecelakaan dapat ditekan apabila tidak terjadi pelanggaran lalu lintas, lampu lalu lintas lebih memberi aturan yang jelas pada saat melalui simpang, simpang bersinyal dapat mengurangi konflik yang terjadi pada simpang, terutama pada jam sibuk, pada saat lalu lintas sepi, simpang bersinyal menyebabkan adanya tundaan yang seharusnya tidak terjadi.

Dilihat dari bentuknya terdapat dua macam jenis persimpangan yaitu pertemuan atau persimpangan jalan sebidang dan pertemuan atau persimpangan jalan tidak sebidang (Abubakar, 1995). Sesuai dengan kondisi lalu lintasnya, di mana terdapat pertemuan jalan 
dengan arah pergerakan yang berbeda, simpang sebidang merupakan lokasi yang potensial untuk menjadi titik pusat konflik lalu lintas yang bertemu, penyebab kemacetan, akibat perubahan kapasitas, tempat terjadinya kecelakaan, konsentrasi para penyeberang jalan atau pedestrian (Wibowo, 2001). Salah satu perlengkapan pengendalian simpang adalah perbaikan kecil tertentu yang dapat dilakukan untuk semua jenis persimpangan yang dapat meningkatkan keselamatan dan efisiensi yang meliputi kanalisasi, pelebaran jalan, lajur-lajur percepatan dan perlambatan, lajur-lajur belok kanan, pengendalian terhadap pejalan kaki (Abubakar, 1995).

\subsection{Manajemen Lalu Lintas}

Manajemen lalu lintas adalah suatu proses pengaturan dan penggunaan sistem jalan yang sudah ada dengan tujuan untuk memenuhi suatu kepentingan tertentu, tanpa perlu penambahan atau pembuatan infrastruktur baru (Malkhamah, 2003). Tujuan pokok manajemen lalu lintas adalah memaksimumkan pemakaian sistem jalan yang ada dan meningkatkan keamanan jalan, tanpa merusak kualitas lingkungan (Hobbs, 1995). Arus lalu lintas berinteraksi dengan sistem jaringan transportasi. Jika arus lalu lintas meningkat pada ruas jalan tertentu, waktu tempuh pasti bertambah. Hal ini disebabkan karena kecepatan menurun. Arus maksimum yang dapat melewati suatu ruas jalan bisa disebut kapasitas ruas jalan tersebut (Tamin, 1997).

Menurut Keputusan Menteri Perhubungan No. 62 tahun 1993, Alat Pemberi Isyarat Lalu Lintas (APILL), adalah perangkat peralatan teknis yang menggunakan isyarat lampu untuk mengatur lalu lintas orang dan atau kendaraan di persimpangan atau ruas jalan. Sedangkan menurut (Malkhamah, 2003), Alat Pemberi Isyarat Lalu Lintas (APILL) atau lampu lalu lintas merupakan alat pengatur lalu lintas yang mempunyai fungsi utama sebagai pengatur hak berjalan pergerakan lalu lintas (termasuk pejalan kaki) secara bergantian di pertemuan jalan. Prinsip dasar pengendalian persimpangan dengan alat pemberi isyarat lalu lintas harus memenuhi aturan yang disampaikan oleh isyarat lampu tersebut dengan tiga warna yaitu hijau, kuning, merah (Abubakar, 1995). Penggunaan sinyal pada lampu tiga warna ini bertujuan untuk memisahkan lintas dari gerakan-gerakan lalu lintas yang bertentangan dalam dimensi waktu. Hal ini adalah mutlak bagi gerakan-gerakan lalu lintas yang datang dari jalan saling konflik. Sinyal juga dapat digunakan untuk memisahkan gerakan konflik yaitu gerakan membelok dari lalu lintas lurus, melawan, atau untuk memisahkan gerakan lalu lintas membelok dari pejalan kaki yang menyeberang (Manual Kapasitas Jalan Indonesia, 1997).

Karakteristik geometrik jalan merupakan gambaran suatu simpang dengan informasi mengenai kereb, jalur, lebar bahu dan median. Geometrik persimpangan harus dirancang sehingga mengarahkan pergerakan (manuver) lalu lintas ke dalam lintasan yang paling aman dan paling efisien sehingga dapat memberikan waktu yang cukup bagi para pengemudi untuk membuat keputusan-keputusan yang diperlukan dalam mengendalikan kendaraannya (Abubakar, 1995). Elemen-elemen geometrik suatu persimpangan secara umum memberikan pengaruh terhadap operasional lalu lintas (Hendarto, 2001). Elemen-elemen tersebut adalah alinemen dan propel, lebar dan jumlah lajur serta elemen-elemen lainnya yang berpengaruh terhadap perencanaan atau persimpangan. 


\subsection{Pengertian Pelanggaran Lalu Lintas}

Pelanggaran adalah perbuatan pidana yang tergolong tidak seberat kejahatan (Soekanto, 1990). Sedangkan menurut kamus besar bahasa Indonesia Pelanggaran adalah perbuatan atau perkara melanggar, tindak pidana yang lebih ringan dari pada kejahatan. Pelanggaran dalam hal ini dideskripsikan pelanggaran lalu lintas sebagai masyarakat yang lalai. Pelanggar lalu lintas bukanlah berkaitan dengan nama atau pekerjaanya. Penegak hukum harus menyadari bahwa pelanggaran lalu lintas (dalam kebanyakan hal) bukanlah penjahat, akan tetapi orang yang lalai atau alpa. Sudah tentu bahwa penegak hukum harus selalu siap menghadapi kenyataan, apabila pelanggaran ternyata adalah penjahat yang sedang melarikan diri. Akan tetapi, pada umumnya pelanggaran adalah warga masyarakat yang lalai, oleh karena mengambil keputusan yang keliru (Soekanto, 1990).

\section{$2.4 \quad$ Uji beda}

Uji t dua sampel independen (bebas) adalah metode yang digunakan untuk menguji kesamaan rata-rata dari dua populasi yang bersifat independen, di mana peneliti tidak memiliki informasi mengenai ragam populasi. Independen maksudnya adalah bahwa populasi yang satu tidak dipengaruhi atau tidak berhubungan dengan populasi yang lain. Bisa dikatakan juga bahwa uji t dua sampel bebas yang dimaksud adalah sampel yang tidak berpasangan, artinya bahwa sumber data berasal dari subjek yang berbeda.

Uji beda dilakukan dengan dua alternatif metode yaitu uji statistik parametrik atau uji statistik non-parametrik. Penentuan pemakaian metode uji dilakukan berdasarkan hasil uji normalitas (Kolmogorov-Smirnov Test). Bila hasil uji menunjukkan data terdistribusi normal maka digunakan uji statistik parametrik (Subiyakto, 1994). Uji parametrik juga menuntut bahwa nilai-nilai yang dianalisis merupakan hasil dari suatu pengukuran minimal dengan skala interval (Wahid, 2002). Uji parametrik yang digunakan dalam penelitian ini adalah uji beda $t$ berpasangan (paired sample t-test). Uji beda t-test digunakan untuk menentukan apakah dua sampel yang tidak berhubungan memiliki nilai rata-rata yang berbeda (Ghozali, 2006). Uji beda t-test dilakukan dengan cara membandingkan perbedaan rata-rata dua sampel.

$$
\mathrm{t}=\frac{\text { ratarata sampel pertama }- \text { ratarata sampel kedua }}{\text { standart error perbedaan kedua sampel }}
$$

dengan rumusan hipotesis sebagai berikut :

$H_{0}$ : tidak terdapat perbedaan signifikan antara rata-rata sampel pertama dengan rata-rata sampel kedua.

$H_{a}$ : terdapat perbedaan signifikan antara rata-rata sampel pertama dengan rata-rata sampel kedua.

Pengambilan keputusan didasarkan pada perbandingan nilai probabilitas yang dihasilkan model uji dengan nilai tingkat kepercayaan $(\alpha=0,05)$ yang digunakan dalam penelitian ini.

$H_{0}$ diterima jika probabilitas ( $\mathrm{p}$ value $) \geq 0,05 \alpha$

$H_{0}$ ditolak jika probabilitas ( $\mathrm{p}$ value $)<0,05 \alpha$ 
Uji statistik non-parametrik adalah uji yang modelnya tidak menetapkan syarat-syarat mengenai parameter-parameter populasi. Anggapan-anggapan tertentu dikaitkan dengan sejumlah besar tes-tes non-parametrik, yaitu bahwa observasi-observasinya independen dan bahwa variabel yang diteliti pada dasarnya memiliki kontinuitas. Sebagian besar tes nonparametrik dapat diterapkan untuk data dalam skala ordinal dan beberapa yang lain juga dapat diterapkan untuk data dalam skala nominal (Wahid, 2002). Uji non parametrik yang digunakan dalam penelitian biasanya uji Willcoxon. Uji Willcoxon adalah uji non parametrik yang didasarkan atas dasar ranking dan uji ini akan sangat bermanfaat jika data yang digunakan adalah data yang berskala ordinal. Uji Willcoxon digunakan untuk mengisi signifikansi hipotesis komparatif dua sampel independen yang berukuran sama dan datanya berbentuk ordinal (Wahid, 2002). Uji ini paling sering digunakan oleh peneliti ketika ingin menghindari asumsi-asumsi dari statistik uji-t (misalnya data sampel mengikuti distribusi normal).

Analisis varians (ANOVA) dipergunakan untuk menguji perbedaan rata-rata hitung jika kelompok sampel yang diuji lebih dari dua buah yang berasal dari populasi yang berbeda. Namun, jika dikehendaki, uji ANOVA dapat juga dipergunakan walau kelompok itu hanya dua buah. Dengan demikian, anova dapat dipandang sebagai teknik t-tes yang diperluas. Hasil perhitungan uji analisis varians dinyatakan dengan nilai F (Nurgiyantoro, 2002).

\section{Metode Penelitian}

Metode penelitian yang dipakai adalah deskriptif evaluatif, yaitu metode penelitian yang mengevaluasi kondisi objektif/apa adanya pada suatu keadaan yang menjadi obyek studi. Obyek studi yang dimaksud adalah pelanggaran lalu lintas di simpang empat Bendogantungan Klaten. Penelitian ini memberikan gambaran tentang keadaan kota Klaten atau fenomena secara sistematis dan akurat mengenai fakta-fakta pada saat penelitian dilakukan (masalah-masalah yang bersifat aktual).

Data yang dibutuhkan adalah data sekunder dan primer. Oleh karena itu teknik pengumpulan data yang digunakan adalah teknik dokumentasi, studi literatur dan observasi lapangan. Data sekunder berupa laporan-laporan instansi terkait dan studi literatur mengenai pelanggaran lalu lintas. Sedangkan data primer mencatat banyaknya sepeda motor dan banyaknya kendaraan yang melanggar lalu lintas di simpang empat Bendogantungan Klaten. Tidak semua data penduduk di daerah yang sama menjadi obyek penelitian, namun hanya data yang termasuk dalam kategori.

Tahap analisis data, meliputi analisis faktor-faktor yang mempengaruhi pelanggaran lalu lintas di kota Klaten, dampak pelanggaran lalu lintas, menguji beda pelanggaran lalu lintas berdasarkan lokasi sisi utara, selatan, timur dan barat menggunakan one way ANOVA. Hasil analisis adalah output yang berupa masukan bagi kota Klaten untuk mempertimbangkan waktu henti pada traffic light.

\section{Pembahasan}

\subsection{Faktor-faktor yang mempengaruhi pelanggaran lalu lintas}

Pola pikir masyarakat yang praktis dalam berkendara di jalan raya telah melahirkan masyarakat instan baik saat berkendara maupun diluar berkendara. Masyarakat instan ini kemudian mendorong lenturnya etika dalam berkendara di jalan raya, dan menimbulkan berbagai macam pelanggaran lalu lintas sehingga banyak kecelakaan terjadi. Kecelakaan di Indonesia hampir selalu terjadi setiap hari dikarenakan kesalahan pengemudi itu sendiri. Kecelakan juga banyak terjadi karena faktor lain, diantaranya adalah karena pengemudi tidak mematuhi peraturan lalu lintas untuk menjaga keselamatan, keamanan dan juga kelancaran 
lalu lintasnya juga. Masyarakat Indonesia masih banyak yang belum sadar atas pentingnya peraturan lalu lintas dan hal ini yang harus diperhatikan oleh pihak yang bersangkutan maupun pemerintah.

Berikut ini adalah pendapat penulis tentang penyebab terjadinya pelanggaran lalu lintas yang sering terjadi di Klaten :

1. Minimnya pengetahuan masyarakat terhadap peraturan lalu lintas yang berlaku di Indonesia hal tersebut dikarenakan kurangnya kesadaran masyarakat untuk mencari tahu peraturan lalu lintas atau rambu-rambu lalu lintas.

2. Alasan waktu yang sedikit sehingga terburu buru dalam berkendara.

3. Semenjak kecil seorang anak kecil sudah di perbolehkan membawa kendaraan bermotor yang seharusnya umurnya belum mencukupi untuk berkendara sehingga mereka sering melanggar peraturan lalu lintas karna belum mengetahui peraturan-peraturan lalu lintas.

4. Hanya patuh ketika ada kabar bahwa akan ada razia atau saat ada polisi.

5. Tidak memikirkan keselamatan pengendara lain atau masyarakat yang ada di sekitar jalan. Contohnya pengendara motor tidak memakai helm, kaca spion dan tidak menyalakan lampu di siang hari.

6. Bisa langsung mengurus pelanggaran lalu lintas di tempat atau dengan kata lain "damai". Hal ini sering terjadi di setiap ada rajia polisi atau pelanggaran lalu lintas.

Adapun bentuk-bentuk pelanggaran lalu lintas yang sering terjadi di Klaten menurut pengamatan penulis adalah sebagai berikut:

1. Berkendara tidak memakai sistem pengaman yang lengkap seperti pengendara motor tidak memakai helm ataupun helm yang tidak standar SNI, pengendara mobil tidak memakai safety belt.

2. Menggunakan jalan dengan membahayakan diri sendiri ataupun pengendara lain, hal ini banyak faktor penyebabnya diantaranya pengendara dalam keadaan mabuk atau dalam keadaan terburu-buru.

3. Pengendara melanggar lampu rambu lalu lintas, hal ini yang sering terjadi di setiap perempatan atau pertigaan yang terdapat lampu rambu lalu lintas, kebanyakan para pengendara melanggar lampu rambu lalu lintas karena sedang terburu atau malas menunggu lampu merah terlalu lama.

4. Tidak membawa surat-surat kendaraan STNK dan SIM.

5. Membiarkan kendaraaan bermotor yang ada dijalan tidak memakai plat nomor atau plat nomor yang sah sesuai dengan STNK.

6. Tidak mematuhi perintah petugas pengatur lalu lintas.

\subsection{Dampak pelanggaran lalu lintas}

Banyaknya pelanggaran lalu lintas di kota Klaten mengakibatkan budaya pelanggaran lalu lintas semakin merajalela, berikut adalah dampak dari pelanggaran lalu lintas di kota Klaten:

1. Tingginya angka kecelakan dipersimpangan atau perempatan maupun dijalan raya.

2. Keselamatan pengendara yang mengunakan jalan menjadi terancam bahkan pejalan kaki yang menyeberang jalan maupun berjalan di trotoar.

3. Kemacetan lalu lintas yang semakin parah dikarenakan para pengendara tidak mematuhi peraturan maupun rambu-rambu lalu lintas.

4. Kebiasaan para pengendara yang melanggar lalu lintas sehingga menjadi budaya melanggar peraturan lalu lintas. 


\subsection{Upaya yang harus dilakukan pemerintah kota Klaten dalam mengatasi pelanggaran lalu lintas}

Berikut ini adalah pendapat penulis tentang upaya yang harus dilakukan oleh pemerintah dalam mengatasi pelanggaran lalu lintas di Kota Klaten yang setiap harinya sering terjadi.

1. Pemerintah harus lebih bersosialisasi ke masyarakat dalam peraturan-peraturan lalu lintas, sehingga masyarakat menjadi tahu peraturan-peraturan lalu lintas yang berlaku atau yang baru diterapkan.

2. Pemerintah harus menindak lanjuti petugas-petugas yang tidak mendukungnya hukum pidana atau petugas yang menyelesaikan masalah pelanggaran lalu lintas di tempat dalam kata lain jalur "damai".

3. Pendidikan bagi pengemudi. Hal ini bertujuan untuk menghasilkan pengemudi pengendara bermotor cakap dan terampil dalam mencegah kecelakaan maupun pelanggaran lalu lintas.

4. Menambah atau memperbaiki rambu-rambu lalu lintas yang ada dijalan.

\subsection{Uji beda pelanggaran lalu lintas berdasarkan lokasi pelanggarannya}

Warga kota klaten terbukti di atas kertas "gemar" melakukan pelanggaran lalu lintas. Pasalnya banyak pelanggaran lalu lintas saat penelitian ini dilakukan. Dengan menggunakan taraf signifikansi 5\% maka akan diuji hipotesis apakah terdapat perbedaan yang signifikan di simpang empat Bendogantungan Klaten yaitu pelanggaran di jalan Empu Sedah, jalan Ki Ageng Pandanaran, jalan Yogya-Solo arah timur dan jalan Yogya-Solo arah barat.

\section{A. Pelanggaran arah lurus}

Hasil uji homogenitas pada pelanggaran arah lurus simpang 4 Bendogantungan Klaten menggunakan SPSS 15 adalah sebagai berikut.

Tabel 1. Uji homogenitas pelanggaran arah lurus

\section{Descriptives}

\begin{tabular}{lrrrrrrrr}
\hline & & \multicolumn{1}{c}{$\begin{array}{c}\text { Std. } \\
\text { Deviation }\end{array}$} & $\begin{array}{c}\text { Std. Error } \\
\end{array}$ & \multicolumn{1}{c}{$\begin{array}{c}\text { M5\% Confidence } \\
\text { Interval for Mean }\end{array}$} & Minimum & Maximum \\
\cline { 2 - 9 } & Lower & Upper & Lower & Upper & Lower & Upper & Lower & Upper \\
& Bound & Bound & Bound & Bound & Bound & Bound & Bound & Bound \\
\hline Arah Empu Sedah & 12 & 22,8333 & 14,91085 & 4,30439 & 13,3594 & 32,3072 & 6,00 & 65,00 \\
Ki Ageng Pandanaran & 12 & 33,3333 & 22,39453 & 6,46475 & 19,1045 & 47,5621 &, 00 & 79,00 \\
Yogya-Solo arah timur & 12 & 81,2500 & 55,67132 & 16,07092 & 45,8781 & 116,6219 & 2,00 & 159,00 \\
Yogya-Solo arah barat & 12 & 108,1667 & 66,65083 & 19,24044 & 65,8187 & 150,5146 & 8,00 & 243,00 \\
\hline Total & 48 & 61,3958 & 56,34156 & 8,13220 & 45,0359 & 77,7557 &, 00 & 243,00 \\
\hline
\end{tabular}

Test of Homogeneity of Variances

\begin{tabular}{ccccc}
\hline $\begin{array}{c}\text { Levene } \\
\text { Statistic }\end{array}$ & $\mathrm{df1}$ & & $\mathrm{df2}$ & Sig. \\
\hline 8,023 & & 3 & 44 &, 000 \\
\hline
\end{tabular}

Data diatas adalah data heterogen, karena nilai signifikansi $<0,05$ sehingga bisa di lanjutkan untuk uji post hoc Test 
Tabel 2. Uji beda pelanggaran arah lurus

ANOVA

\begin{tabular}{lcrrrr}
\hline & $\begin{array}{c}\text { Sum of } \\
\text { Squares }\end{array}$ & df & Mean Square & F & Sig. \\
\hline Between Groups & 58275,229 & 3 & 19425,076 & 9,401 &, 000 \\
Within Groups & 90920,250 & 44 & 2066,369 & & \\
\hline Total & 149195,479 & 47 & & & \\
\hline
\end{tabular}

Terlihat bahwa nilai signifikansi $0,000<0,05$ sehingga terdapat beda pelanggaran di 4 titik lampu lalu lintas. Hal ini terlihat juga pada nilai $F_{\text {hitung }}$ yang lebih besar dari $F_{\text {tabel }}$ yaitu $9,401>0,05$

Tabel 3. Detail Uji beda pelanggaran arah lurus

\begin{tabular}{|c|c|c|c|c|c|c|}
\hline \multicolumn{7}{|c|}{ Multiple Comparisons } \\
\hline \multirow[t]{2}{*}{ (I) grup } & \multirow[t]{2}{*}{ (J) grup } & $\begin{array}{c}\text { Mean } \\
\text { Difference } \\
(\mid-J)\end{array}$ & Std. Error & Sig. & \multicolumn{2}{|c|}{$95 \%$ Confidence Interval } \\
\hline & & Lower Bound & $\begin{array}{l}\text { Upper } \\
\text { Bound }\end{array}$ & $\begin{array}{l}\text { Lower } \\
\text { Bound }\end{array}$ & Upper Bound & Lower Bound \\
\hline \multirow[t]{3}{*}{ Arah Empu Sedah } & ki ageng pandanaran & $-10,50000$ & 18,55788 &, 574 & $-47,9009$ & 26,9009 \\
\hline & yogya-solo arah timur & $-58,41667\left(^{\star}\right)$ & 18,55788 &, 003 & $-95,8176$ & $-21,0157$ \\
\hline & yogya-solo arah barat & $-85,33333\left(^{\star}\right)$ & 18,55788 &, 000 & $-122,7343$ & $-47,9324$ \\
\hline \multirow[t]{3}{*}{ Ki Ageng Pandanaran } & arah empu sedah & 10,50000 & 18,55788 & ,574 & $-26,9009$ & 47,9009 \\
\hline & yogya-solo arah timur & $-47,91667\left(^{*}\right)$ & 18,55788 & 013 & $-85,3176$ & $-10,5157$ \\
\hline & yogya-solo arah barat & $-74,83333\left(^{\star}\right)$ & 18,55788 &, 000 & $-112,2343$ & $-37,4324$ \\
\hline \multirow[t]{3}{*}{$\begin{array}{l}\text { Yogya-Solo arah } \\
\text { timur }\end{array}$} & arah empu sedah & $58,41667\left(^{*}\right)$ & 18,55788 &, 003 & 21,0157 & 95,8176 \\
\hline & ki ageng pandanaran & $47,91667\left(^{\star}\right)$ & 18,55788 &, 013 & 10,5157 & 85,3176 \\
\hline & yogya-solo arah barat & $-26,91667$ & 18,55788 &, 154 & $-64,3176$ & 10,4843 \\
\hline \multirow[t]{3}{*}{$\begin{array}{l}\text { Yogya-Solo arah } \\
\text { barat }\end{array}$} & arah empu sedah & $85,33333\left(^{*}\right)$ & 18,55788 &, 000 & 47,9324 & 122,7343 \\
\hline & ki ageng pandanaran & $74,83333\left({ }^{*}\right)$ & 18,55788 &, 000 & 37,4324 & 112,2343 \\
\hline & yogya-solo arah timur & 26,91667 & 18,55788 & , 154 & $-10,4843$ & 64,3176 \\
\hline
\end{tabular}

* The mean difference is significant at the .05 level.

Dari tabel diatas, diketahui bahwa pelanggaran arah lurus di jalan Empu Sedah tidak ada perbedaan dengan pelanggaran arah lurus di jalan Ki Ageng Pandanaran. Hal ini dikarenakan nilai signifikansi $0,574>0,05$. Terdapat perbedaan yang signifikan antara pelanggaran arah lurus jalan Empu Sedah dengan pelanggaran arah lurus di jalan YogyaSolo arah timur dengan nilai signifikansi $0,003<0,05$. Pelanggaran arah lurus Empu Sedah juga terjadi berbedaan yang signifikan dibandingkan dengan pelanggaran di jalan Yogya-Solo arah barat dengan nilai signifikansi $0,000<0,05$.

Pelanggaran arah lurus di jalan Ki Ageng Pandanaran berbeda dengan pelanggaran arah lurus di jalan Yogya-Solo arah timur. Hal ini dikarenakan nilai signifikansi $0,013<0,05$. Terdapat perbedaan yang signifikan pula antara pelanggaran arah lurus di jalan Ki Ageng Pandanaran pelanggaran di jalan Yogya-Solo arah barat dengan nilai signifikan $0,000<0,05$.

Pelanggaran arah lurus di jalan Yogya-Solo arah timur dibandingkan dengan pelanggaran di jalan Yogya-Solo arah barat tidak terjadi perbedaan yang signifikan karena nilai signifikansi $0,154>0,05$. 


\section{B. Pelanggaran arah Belok Kanan}

Hasil uji homogenitas pada pelanggaran arah belok kanan simpang empat Bendogantungan Klaten menggunakan SPSS 15 adalah sebagai berikut :

Tabel 4. Uji homogenitas pelanggaran belok kanan

Descriptives

\begin{tabular}{|c|c|c|c|c|c|c|c|c|}
\hline & $\mathrm{N}$ & Mean & $\begin{array}{c}\text { Std. } \\
\text { Deviation }\end{array}$ & Std. Error & $\begin{array}{c}\text { 95\% } \\
\text { Confidenc } \\
\text { e Interval } \\
\text { for Mean }\end{array}$ & Minimum & \multicolumn{2}{|c|}{ Maximum } \\
\hline & $\begin{array}{l}\text { Lower } \\
\text { Bound }\end{array}$ & $\begin{array}{l}\text { Upper } \\
\text { Bound }\end{array}$ & $\begin{array}{l}\text { Lower } \\
\text { Bound }\end{array}$ & $\begin{array}{l}\text { Upper } \\
\text { Bound }\end{array}$ & $\begin{array}{l}\text { Lower } \\
\text { Bound }\end{array}$ & $\begin{array}{l}\text { Upper } \\
\text { Bound }\end{array}$ & $\begin{array}{l}\text { Lower } \\
\text { Bound }\end{array}$ & $\begin{array}{l}\text { Upper } \\
\text { Bound }\end{array}$ \\
\hline Arah Empu Sedah & 12 & 25,5000 & 17,13847 & 4,94745 & 14,6107 & 36,3893 & 12,00 & 67,00 \\
\hline Ki Ageng Pandanaran & 12 & 39,4167 & 14,88415 & 4,29668 & 29,9597 & 48,8736 & 14,00 & 65,00 \\
\hline Jogja Solo arah timur & 12 & 53,1667 & 30,82453 & 8,89827 & 33,5817 & 72,7516 & 1,00 & 89,00 \\
\hline Jogja Solo arah barat & 12 & 192,1667 & 108,80995 & 31,41073 & 123,0321 & 261,3012 & 12,00 & 317,00 \\
\hline Total & 48 & 77,5625 & 87,65185 & 12,65146 & 52,1111 & 103,0139 & 1,00 & 317,00 \\
\hline
\end{tabular}

Test of Homogeneity of Variances

\begin{tabular}{ccccc}
\hline $\begin{array}{c}\text { Levene } \\
\text { Statistic }\end{array}$ & df1 & & df2 & Sig. \\
\hline 14,451 & 3 & 44 &, 000 \\
\hline
\end{tabular}

Data diatas adalah data heterogen, karena nilai signifikansi $<0,05$ sehingga bisa di lanjutkan untuk uji post hoc Test

Tabel 5. Uji beda pelanggaran arah lurus

\begin{tabular}{lcrrrrr}
\hline \multicolumn{7}{c}{ ANOVA } \\
& Sum of & & & & \\
Squares & df & & Mean Square & F & Sig. \\
\hline Between Groups & 214738,562 & & 3 & 71579,521 & 21,520 &, 000 \\
Within Groups & 146355,250 & 44 & 3326,256 & & \\
\hline Total & 361093,813 & 47 & & & \\
\hline
\end{tabular}

Terlihat bahwa nilai signifikansi $0,000<0,05$ sehingga ada beda pelanggaran di 4 titik lampu lalu lintas dan $F_{\text {hitung }}>F_{\text {tabel }}$ yaitu $9,401>0,05$

Tabel 6. Detail Uji beda pelanggaran belok kanan

Multiple Comparisons

\begin{tabular}{|c|c|c|c|c|c|c|}
\hline \multirow[t]{2}{*}{ (I) grup } & \multirow[t]{2}{*}{ (J) grup } & $\begin{array}{c}\text { Mean } \\
\text { Difference (I-J) }\end{array}$ & Std. Error & Sig. & \multicolumn{2}{|c|}{$95 \%$ Confidence Interval } \\
\hline & & Lower Bound & $\begin{array}{l}\text { Upper } \\
\text { Bound }\end{array}$ & $\begin{array}{l}\text { Lower } \\
\text { Bound }\end{array}$ & $\begin{array}{l}\text { Upper } \\
\text { Bound }\end{array}$ & $\begin{array}{l}\text { Lower } \\
\text { Bound }\end{array}$ \\
\hline \multirow[t]{3}{*}{ arah empu sedah } & ki ageng pandanaran & $-13,91667$ & 23,54519 &, 558 & $-61,3689$ & 33,5355 \\
\hline & jogja solo arah timur & $-27,66667$ & 23,54519 &, 246 & $-75,1189$ & 19,7855 \\
\hline & jogja solo arah barat & $-166,66667\left(^{\star}\right)$ & 23,54519 &, 000 & $-214,1189$ & $-119,2145$ \\
\hline \multirow[t]{3}{*}{ ki ageng pandanaran } & arah empu sedah & 13,91667 & 23,54519 &, 558 & $-33,5355$ & 61,3689 \\
\hline & jogja solo arah timur & $-13,75000$ & 23,54519 &, 562 & $-61,2022$ & 33,7022 \\
\hline & jogja solo arah barat & $-152,75000\left(^{*}\right)$ & 23,54519 &, 000 & $-200,2022$ & $-105,2978$ \\
\hline jogja solo ara & arah empu sedah & 27,66667 & 23,54519 &, 246 & $-19,7855$ & 75,1189 \\
\hline
\end{tabular}


Tabel 6 (lanjutan). Detail Uji beda pelanggaran belok kanan

\begin{tabular}{|c|c|c|c|c|c|c|}
\hline \multirow[t]{2}{*}{ (I) grup } & \multirow[t]{2}{*}{ (J) grup } & $\begin{array}{c}\text { Mean } \\
\text { Difference }(\mid-J)\end{array}$ & Std. Error & Sig. & \multicolumn{2}{|c|}{$95 \%$ Confidence Interval } \\
\hline & & Lower Bound & $\begin{array}{l}\text { Upper } \\
\text { Bound }\end{array}$ & $\begin{array}{l}\text { Lower } \\
\text { Bound }\end{array}$ & $\begin{array}{l}\text { Upper } \\
\text { Bound }\end{array}$ & $\begin{array}{l}\text { Lower } \\
\text { Bound }\end{array}$ \\
\hline & \multirow{2}{*}{$\begin{array}{l}\text { ki ageng pandanaran } \\
\text { jogja solo arah barat }\end{array}$} & 13,75000 & 23,54519 &, 562 & $-33,7022$ & 61,2022 \\
\hline & & $-139,00000\left(^{*}\right)$ & 23,54519 &, 000 & $-186,4522$ & $-91,5478$ \\
\hline \multirow[t]{3}{*}{ jogja solo arah barat } & arah empu sedah & $166,66667\left(^{*}\right)$ & 23,54519 &, 000 & 119,2145 & 214,1189 \\
\hline & \multirow{2}{*}{$\begin{array}{l}\text { ki ageng pandanaran } \\
\text { jogja solo arah timur }\end{array}$} & $152,75000\left(^{*}\right)$ & 23,54519 &, 000 & 105,2978 & 200,2022 \\
\hline & & $139,00000\left(^{*}\right)$ & 23,54519 &, 000 & 91,5478 & 186,4522 \\
\hline
\end{tabular}

Dari tabel diatas, diperoleh bahwa pelanggaran arah belok kanan di jalan Empu Sedah tidak ada perbedaan dengan pelanggaran arah belok kanan di jalan Ki Ageng Pandanaran karena nilai signifikansi $0,558>0,05$. Tidak terdapat perbedaan yang signifikan antara pelanggaran arah belok kanan jalan Empu Sedah dibandingkan dengan pelanggaran arah belok kanan di jalan Yogya-Solo arah timur. Hal ini dikarenakan nilai signifikansi $0,246>0,05$. Pelanggaran arah belok kanan Empu Sedah dibandingkan dengan pelanggaran di jalan Yogya-Solo arah barat terjadi perbedaan yang signifikan karena nilai signifikansi $0,000<0,05$.

Pelanggaran arah belok kanan di jalan Ki Ageng Pandanaran dibandingkan dengan pelanggaran arah belok kanan di jalan Yogya-Solo arah timur tidak terjadi perbedaan yang signifikan. Hal ini dikarenakan nilai signifikansi 0,562 $>0,05$. Sedangkan pelanggaran arah belok kanan di jalan Ki Ageng Pandanaran dibandingkan dengan pelanggaran di jalan YogyaSolo arah barat terjadi perbedaan yang signifikan dengan nilai signifikansi $0,000<0,05$.

Terdapat berbedaan yang signifikan antara pelanggaran arah lurus di jalan Yogya-Solo arah timur dengan pelanggaran di jalan Yogya-Solo arah barat dengan nilai signifikansi $0,00<0,05$.

\section{Kesimpulan}

Masyarakat Klaten masih banyak yang melanggar lalu lintas dengan tidak sengaja maupun dengan sengaja. Hal ini disebabkan karena kurangnya pengetahuan masyarakat terhadap peraturan lalu lintas atau tata tertib lalu lintas, sehingga masyarakat menyepelekan kesalamatannya sendiri bahkan bisa berdampak terhadap keselamatan orang lain, sehingga tingkat kecelakan di jalan terus meningkat. Pada umumnya penyebab pelanggaran lalu lintas adalah waktu yang sedikit sehingga terburu-buru dalam berkendara dan memicu kemacetan lalu lintas.

Pelanggaran arah lurus di jalan Empu Sedah tidak ada perbedaan dengan pelanggaran arah lurus di jalan Ki Ageng Pandanaran. Terdapat perbedaan yang signifikan jika dibandingkan dengan pelanggaran arah lurus di jalan Yogya-Solo arah timur dan di jalan Yogya-Solo arah barat. Pelanggaran arah lurus di jalan Ki Ageng Pandanaran berbeda dengan pelanggaran arah lurus di jalan Yogya-Solo arah timur dan di jalan Yogya-Solo arah barat. Sedangkan pelanggaran arah lurus di Jalan Yogya-Solo arah timur dengan pelanggaran di jalan Yogya-Solo arah barat tidak terjadi perbedaan. 
Pelanggaran arah belok kanan di jalan Empu Sedah tidak ada perbedaan dengan pelanggaran arah belok kanan di jalan Ki Ageng Pandanaran dan di jalan Yogya-Solo arah timur. Jika dibandingkan dengan pelanggaran di jalan Yogya-Solo arah barat terjadi berbedaan yang signifikan. Pelanggaran arah belok kanan di jalan Ki Ageng Pandanaran dibandingkan dengan pelanggaran arah belok kanan di jalan Yogya-Solo arah timur tidak terjadi perbedaan yang signifikan, sedangkan jika dibandingkan dengan pelanggaran di jalan Yogya-Solo arah barat terjadi perbedaan yang signifikan. Pelanggaran arah lurus di jalan Yogya-Solo arah timur dibandingkan dengan pelanggaran di jalan Yogya-Solo arah barat terjadi perbedaan yang signifikan karena nilai signifikansi $0,00<0,05$.

\section{Daftar Pustaka}

AASHTO, 2001, A Policy on Geometric Design of Highways and Streets, fourth Edition, Washington D.C

Abubakar, 1995, Rekayasa dan Manajemen Lalu Lintas, Direktorat Jenderal Perhubungan Darat, Departemen Perhubungan, Jakarta.

Ghozali, Imam, 2006. Aplikai Analisis Multivarite dengan SPSS, Cetakan Keempat, Badan Penerbit Universitas Diponegoro, Semarang.

Hendarto, Sri dkk. 2001. Dasar-dasar Transportasi. Bandung : ITB.

Hobbs, F., D., (1995). Perencanaan dan Teknik Lalu-lintas, Gadjah Mada University Press, Yogyakarta.

Manual Kapasitas Jalan Indonesia (MKJI). 1997. Departemen Pekerjaan umum : Bina Marga.

Morlok, Edward K. 1991. Pengantar Teknik dan Perencanaan Transportasi. Alih Bahasa Ir. Johan Kelanaputra Hainim. Erlangga.

Malkhamah S, 2003. Dasar-dasar Road Safety Audit, Magister Sistem dan Teknik Transportasi, Fakultas Teknik UGM, Yogyakarta.

Nurgiyantoro, Burhan. 2002. Pengkajian Fiksi. Yogyakarta: Gadjahmada University Press.

Subiyakto, Haryono, 1994, Statistika 2, Jakarta: Gunadarma.

Soekanto, Soerjono, 1990, Polisi dan Lalu Lintas. Bandung: Mandar Maju.

Tamin, O.Z, 1997. Perencanaan dan Pemodelan Transportasi, Teknik Sipil. Institut Teknologi Bandung

Wahid Sulaiman, 2002, Statistik Non Parametrik Disertai Contoh Pemecahan Dengan SPSS

Walpole, Ronald E, 1995, Pengantar Statistika, edisi ke-3, Penerbit PT. Gramedia Pustaka Utama, Jakarta

Wibowo, dkk (2001). Pengantar Rekayasa Jalan. Cetakan Ketiga. Bandung, Indonesia: Institut Teknologi Bandung. 
Ridayati 